\title{
THE INFLUENCE OF THE KESWICK CONVENTION ON MISSIONARY WORK
}

Tre small town of Keswick, situated in the English lake district, has long been familiar as a resort for tourists. It is not, however, because of its surpassing beauty that the name of the little Cumberland town has become known throughout the English-speaking world and far beyond it, but because of the divine blessing granted there, the stream of which has gone forth to quicken and refresh the Church of God.

I am to tell of the influence of the Convention held at Keswick on the missionary movement, but the real extent of that influence can never be fully estimated. In response to an appeal in the magazines of various societies, and in reply to personal letters, the writer has heard from upwards of sixty persons who either received the call to missionary service through Keswick, or who have been stimulated and helped in their ministry by being present there, when on furlough. These represent fifteen societies at work in India, Ceylon, China, Japan, Africa, Madagascar, South America ; and also some engaged in the home side of the foreign mission enterprise. There must, however, be many who from various causes have not responded to the writer's appeal for information ; and we can safely adopt the words of Dr. Eugene Stock when he writes : 'No other single agency can compare with [the Keswick Convention] in fruitfulness in this respect. There is not a mission field which is not indebted to Keswick for one or more of its labourers-in some cases for several of them.'

The first Convention took place in the year 1875 ; the 
meetings were held in a tent, and ever since they have been 'under canvas.' It was convened by the Rev. Canon Harford Battersby, vicar of St. John's, Keswick, and Mr. Robert Wilson of Broughton Grange, Cockermouth. The avowed object of the gathering was the promotion of practical holiness, and the remarkable and far-reaching influence which the Convention eventually came to exercise upon missionary work was entirely outside the vision of the original promoters.

In considering the character of the teaching, which has produced results so remarkable, I must confine myself to the briefest description.

(1) The possibilities of attainment in the Christian life were unfolued from the New Testament and applied in a practical way: this involved no teaching of sinlessness, but it pointed to a life of communion with God through Christ as a reality to be entered upon and constantly maintained.

(2) The entrance on such a life and the continuance in it were shown to depend upon the unconditional and habitual surrender of the whole personality to Christ's control and government, and on the assurance that the living Christ would take possession of the life thus yielded to Him. That the Gospel demands such a surrender is doubtless involved in the teaching of the whole evangelical Church. 'Membership in the Church implies that the measure of Christ's surrender for our salvation is the only true measure of our surrender to Him and His service.' The speakers at Keswick were in line with the Church generally in their statement of this truth; but they called their hearers to come face to face with what Christ's claim involved, and to act upon that claim in a way that gave their message a fresh and unique influence. As men and women were made to realize that the Christ who had given Himself up to death for them called them to give themselves up in like measure to live for Him, the question of what Christ would have them to do for the world became a pressing 45 * 
one. Here, rather than anywhere else, we shall find the cause which year after year at Keswick has constrained such numbers to offer themselves for service in the mission field.

(3) The personality of the Holy Spirit was proclaimed as possessing the truly surrendered heart and as working in and through every surrendered life. As a result those who would otherwise have shrunk from facing the high places of the field now felt emboldened to go forth.

Resulting from these influences there was a rising tide of missionary interest from the commencement of the Convention, but eleven years elapsed before the first public missionary meeting was held, and even then it was not included in the official programme.

Referring to the earliest years, we find that the Rev. A. R. Tucker, afterwards Bishop of Uganda, whose recent death was so greatly deplored, visited the Convention for the first time in the year 1876. He had already been hearing the call to the mission field, but this visit greatly influenced his life and work. He wrote :

'I would even go so far as to say that had I never gone to Keswick, I might never have been a missionary. Since I became a missionary I have received the greatest possible help through my occasional visits to Keswick and $I$ know that this has been the experience of a large number of missionaries with whom I have come closely into contact.'

The year 1885 was one in which the current of the rising tide ran strong. A meeting for prayer on behalf of missions was called unofficially in a large sitting-room at one of the lodgings. At the hour named people continued to come until there was no room even to kneel, and the room was packed with men and women standing. Much prayer was offered and the meeting separated in the assurance that God was about to do great things.

At the testimony meeting on the closing day of the Convention there stood up three young clergymen, one of whom spoke for the party and intimated that they felt themselves called to missionary service. In the case of one 
the way has never opened to the foreign field, another is now the Bishop of Victoria, Hongkong, though it was twenty-two years before he went abroad. The third sailed for India after an interval of two years, and nearly twenty years later he was consecrated Bishop of Travancore. He still looks back to the Keswick Convention as the place where the call came and where he received grace to respond to it.

That same year Mr. A. Orr Ewing, a partner in a large business concern in Scotland, was present for the second time. He writes, 'It was at Keswick the Lord met me and so revealed Himself that all else seemed to take a second place.' The words of the speakers were used to instruct and prepare the way, but the decision that has led to twenty-six years of service in China was made when alone with God.

The following year, 1886, saw the tent granted for the first time for a missionary meeting on the Saturday morning, under the leadership of the late Mr. Reginald Radcliffe, a Liverpool solicitor. A lady was present who was the widow of an Indian official : on Prebendary Webb Peploe's inviting all to rise who were ready to offer themselves to the Lord for foreign service she responded and a station in India, with which she was familiar, was laid specially on her heart. Owing to family circumstances she was delayed at home for six years; then she and her two daughters went out to work, in connexion with the Zenana Bible and Medical Mission, at the very station to which her attention had been directed six years previously.

The year 1887 was probably the turning point in the history of the connexion of Keswick with the missionary movement. Mr. Radcliffe again took the chair at a missionary meeting: Hudson Taylor, Eugene Stock, James Johnson (an African clergyman now a bishop) and others spoke, and an impression was made that resulted in very definite action being taken. Dr. Stock during his address expressed his willingness to see and advise any who desired 
to offer themselves for missionary work. He has placed on record the fact that between Saturday afternoon and Monday morning he had twenty-four long interviews with those who were desirous of offering. A lady writes from Tunis whose service originated through the meeting of that year, and who has seen twenty-five years' work amidst the difficulties and disappointments of the Moslem field. Another offered herself at that meeting whose way had been cleared up during the week in personal conversation with Mr. Hudson Taylor, and she has had about twentyfive years' service in China. To a third the words, "Is it not lawful for me to do what I will with mine own ?' brought a sense of obligation to Christ hitherto unrecognized and three years after she went to China, in connexion with the Church Missionary Society.

In the year 1888 the missionary meeting on the Saturday morning, which had been begun two years previously, was included for the first time in the official programme, and it has been continued ever since. The chair has been occupied by Dr. Eugene Stock and occasionally, in his absence, by the present writer. In this same year a daily meeting for prayer on behalf of missionary work was also commenced at Dr. Stock's suggestion. For some years it only lasted for half an hour each morning after breakfast; in 1906 the time was changed to 7 a.m. and a full hour has since been devoted to intercession.

A missionary who has been at work in South Africa for twenty years writes from Pondoland that he was present in the Saturday meeting in 1889. He listened with unwilling ears to the appeals made, as the one thing he did not want to do was to become a missionary. The next year he went again, but before the Saturday meeting came he had learned that God's will must be accepted in everything, and that the highest good comes on the line of entire abandonment to Him. With a free heart he stood up to offer himself in the missionary meeting and in due time the way opened and he went forth. 
The Convention of 1891 was certainly one of remarkable power and blessing and its influence on missionary work was profound. Dr. Walter Miller of the Church Missionary Society in Hausaland writes that under God he owes his spiritual life to Keswick ; and it was in this year at a special meeting for medical missions, addressed by Mrs. Bird Bishop, that he received his call to the mission field. A Congregational minister from the Midlands was present that year : during the previous year his heart had been exercised upon the subject of missions and he had tried to get others to go abroad. At Keswick on the Saturday the personal call came with the conviction that it must be obeyed, as through the week he had been learning 'that the way of holiness meant absolute and entire obedience,' and the glad response was uttered, 'Lord, may I go, for one, to tell them that they have been redeemed and that they need not perish ?' Since then he has done twentyone years' hard work in India. At the same meeting a young lady stood up to signify her willingness to go abroad. She writes of her experience as follows :

' There were fightings within and fears without. God continually brought before me that text in Joshua i., "All that Thou commandest me I will do and whithersoever Thou sendest me I will go." I could not get away from it and the climax came at a missionary prayer meeting when Miss Gollock rose up to pray and it seemed to me that all she said was, "All that Thou commandest me I will do and whithersoever Thou sendest me I will go." Can you wonder that subsequently at the Saturday meeting I dare not resist the invitation to stand ?"

She and her sister eventually went forth to South Africa, where their ministry is still continued.

The most remarkable feature of that year, however, was the work amongst students, some of whom were present from Cambridge, Edinburgh and Glasgow. One of these, now the Rev. Donald Fraser of the United Free Church of Scotland Mission in Livingstonia, writes as follows :

'I went at a stage when I was scarcely certain of any theological truth. One thing only I was sure of, the Fatherhood of God. When I went I was 
entirely out of sympathy with the Convention, desiring to examine an interesting phase of religious life. The early meetings I found extremely irritating. I thought the exegesis foolish, the logic worse, and the emotionalism got on my nerves. On the Wednesday . . . I was more than ever irritated by the type of the preaching, but at the evening meeting a fearful sense of moral failure came over me, and when Mr. Hopkins began to expound "Where the Spirit of the Lord is there is liberty," light broke and that night I gave myself to God and believed. On the Saturday, when many of us were rejoicing in our deliverance, the missionary meeting came round, and Wilder spoke for a few minutes telling of the Student Volunteer Movement in America, and emphasizing how it had grown out of the work of students for students.'

Mr. Fraser goes on to tell how several students who had been blessed at Keswick went back to Glasgow and gave their personal testimonies to the students in college. Later on Mr. Wilder came and his addresses kindled the flame of zeal which resulted in the foundation of the Student Volunteer Missionary Union in Scotland. For some years after this the Students' Conferences were held at Keswick in the week preceding or in the week following that of the Convention, and Mr. Fraser writes :

' Undoubtedly the influence of the Convention on the Student Volunteer Missionary Union was profound. The claim of the foreign field on men was based on entire surrender to the will of God. The need of being equipped by knowledge of Christ as a complete Saviour and of being possessed by the Holy Ghost was continually emphasized, and the work grew in this atmosphere. . . . It is not easy to trace spiritual origins or growths. But my impression is that the Convention at Keswick created in our colleges the atmosphere which made the student movement possible. Men were led to more complete consecration to Christ, and, therefore, to a greater appreciation of the value of redemption, they were forced to recognize the message they had for the world, and their duty and privilege to proclaim it.'

The name of Douglas Thornton will always recall fragrant and stimulating memories to all who knew him, or who have read his biography. In it we are told of his burning desire to be 'a preacher-prophet all the time,' and how this desire was fulfilled even in the midst of the delirium with which his earthly career was closed. In 1892 he went first to the Students' Conference at Keswick and then he remained for the Convention. His biography 
shows that it was during the latter he obtained the full heart vision of the living person of Christ and His indwelling power which made the whole future of his life so remarkable.

It is impossible to deal in detail with the history of the years up till the present. There are testimonies to show that year by year lives continue to be influenced.

A lady who is engaged in missionary educational work in China tells of her first visit to Keswick in 1899 as follows :

' Formerly my knowledge of Christ had only been as Saviour not as King. Being thoroughly dissatisfied with my life as a Christian led me to Keswick and there my eyes were opened to see I had never welcomed Christ as King. Along with this revelation, there also came the revelation of "Christ in you" as the secret of victory in the everyday life, and the fulness of the Holy Spirit as the secret of power in service.'

The call to the mission field came at the Saturday meeting of the next year. The way was not opened until seven years later, but the call was kept in view and the intervening years were used as years of preparation.

The Convention at Keswick has resulted in similar conventions being held in quite a number of centres throughout the United Kingdom, in which the Keswick speakers have taken part, and these local gatherings also have a record of missionary influence. The Rev. $R$. Wright Hay, now secretary of the Bible League but formerly connected with the Baptist Missionary Society, writes :

- My going out as a missionary first to the West Coast of Africa and then to India was entirely due, under God's sovereign grace, to blessing received while $I$ was a student in Edinburgh through an address given by the Rev. Evan Hopkins in a series of Keswick meetings in that city. I would like to add that both in Africa and in India, notably among Indian students with strong moral aspirations and a humiliating and disheartening consciousness of inability to realize them, I have found the message of deliverance from sin's power effective to persuade to the acceptance of the Lord Jesus Christ when the acceptance meant stupendous sacrifice and the experience of bitter persecution. It was not simply forgiveness that these men sought but also a practical salvation from their sins.'

A missionary of the Church of Scotland tells of leer experience at another of these conventions. When a child 
she formed the purpose of being a missionary and as the years passed the purpose was maintained, and education was carried on with that outlook. Then came some years of ill health, and home circumstances which seemed quite to close the door. This resulted in an attitude of very real rebellion against God's will ; the danger of such a condition was realized in some measure and deliverance sought, but in vain : at last, with very little hope of any help, the convention at Bridge of Allan was attended. She describes her attitude as follows :

"I had decided that "Keswick teaching" could only be of help to those whose religion was of the emotional type. That one might grow into such a blessed life as I had heard of I thought possible, but that one could enter into it by one definite act of faith I considered intellectually impossible, and contrary to the teaching of Scripture. But one night alone in my room at Bridge of Allan I entered in, all the rebellion dropped from me and God's peace and joy took possession and from then till now, through many dark and trying experiences, they have never left me.'

The writer explains that her health soon began to improve and three years later she applied and was accepted for work in Africa, and then she adds :

'I believe that neither my health nor my courage would stand the strain of the life I have lived out here were it not for the keeping and enabling power of the Holy Spirit.'

From year to year about two hundred and fifty missionaries on furlough attend the Keswick Convention. In this way many have been strengthened and encouraged in their work.

From Tunis a missionary writes: 'These meetings and addresses as well as the general teaching and atmosphere of the Keswick Convention have had a great influence on me and have encouraged me to continue my labours on the ungrateful soil of Islam.'

Another writes from Egypt: 'The stimulus and help that the Keswick Convention was to me when home on furlough in 1909 has not been forgotten, and as for the value of the teaching which Keswick stands for, in our actual work on the field, I think it is inestimable. There is no question in my mind as to the value of its worth and perhaps in the mission field, more than anywhere, we are forced into experiencing the practical side of the teaching. Theories do not stand on the mission field.'

Dr. Lewis E. Hertslet writes from Natal : 'For four years before coming 
out here I attended the Convention and once during my furlough. The recollection of the meetings and the fact of the truths there taught are a constant source of inspiration and strength to us in the field. . . . Every year we have a little convention here for Christian natives, run on Keswick lines, and the Lord has blessed us much.'

A letter from Madagascar contains the following: 'I have only attended one convention, that at Guildford (connected with Keswick) nearly twenty years ago-what I learnt there has influenced my life and work for the Master in the mission field ever since. It made me seek and desire above all things a pure heart where the Holy Spirit could make His dwelling place and from that place order all my life to do God's will in the extension of $\mathbf{H i s}$ Kingdom in heathen lands.'

A lady writes from China to tell of the help received by her husband and herself when on furlough; an illustration used by one of the speakers of a man who received as a gift a house into which he himself had put bad workmanship came to them both as a heart searching message. She adds :

'The teaching' of Keswick, where it has touched me most, is best expressed in the text "Neither will I offer unto the Lord my God of that which doth cost me nothing." Keswick is as cold water to the thirsty soul-especially if that soul has been in China, even at its coast, for several years.'

The Keswick Convention has had a powerful influence in the direction of creating a new interest in missionary work on the part of some whose sphere of service lies at home. A Presbyterian minister who went first to the Convention in 1902 tells how he owes the deepest debt to Keswick because it increased his interest in Christ, and this resulted in an increase of missionary purpose and effort. He was 'brought into sympathy with the world passion of the Cross.'

A business man in Lancashire, who is also the leader of a large home mission in a poor district, had his heart stirred by the teaching of the Convention, and after listening to the accounts that different missionaries gave at the missionary meeting he went home realizing that hardly anything was being done in his mission for the needs of the heathen. For many years past more than $£ 50$ per annum has been raised and several missionaries have been sent out. 
A lady who takes a leading part in connexion with the women's department of the foreign missionary work of her Church, writes :

- When I first visited Keswick in r 898 part of the lesson that God taught me was complete surrender to $H$ is will. . . . First came the opening to speak. I was afraid to speak; I disliked women speakers; but the obedience to the voice had been promised and so for years now I have been asked to speak for our women's foreign mission work at meetings of all sorts. Next in order came the invitation to become editor of our women's missionary magazine. I should have liked to refuse, to say that others who were older and more experienced, who had knowledge of proofs and printers might do it, but I knew the call was of God, and so I have been doing it now for ten or twelve years. Next came the knowledge that my children were to be offered to the Lord for the foreign mission field, and I stood at a missionary meeting at Keswick in token of my willingness.'

Mr. J. Martin Cleaver attributes his own interest in missionary work and also the whole origin of the Egypt General Mission and the Nile Mission Press to the influence of the Convention and he adds :

'It provided the attitude of mind in which rightly to hear the call, the atmosphere in which to weigh it, and the driving power of the knowledge-surpassing love of Christ which enabled us to step out in joyful simplicity.'

Miss Agnes M. Boys attended the Convention at Keswick in 1892. There the Lord met with her in a new way and her heart was stirred with missionary zeal. Her way was never opened to go abroad, but in 1894 she founded the Living Waters' Missionary Union, which has sent out thirty-seven missionaries in all, and which at present supports twenty-two missionaries in connexion with seven different missionary societies. The union has enrolled over two thousand members and it not only provides the financial support for these missionaries but it has been the means of awakening much prayer on their behalf.

During the first official missionary meeting in 1888, an envelope was handed up to the chairman containing a $£ 10$ note, with a slip of paper stating that it was given as 'the nucleus of a fund for sending out a Keswick missionary.' This resulted in the formation of the Keswick Mission Fund, which has been utilized in two directions : 
first, in the sending out of missioners through whom the blessing granted at Keswick itself has been spread in other lands, second, in the support of missionaries who work under the direction of recognized missionary societies. The missioners have visited eighteen mission fields, to some of these several visits have been paid and as many as twentyfour speakers have engaged in this work. As a result of the deputations to India, there are now about a dozen conventions for the deepening of spiritual life held annually in various districts. Mr. Robert Wilder says that only those who have lived in India can know how much the missionaries are indebted to these conferences and how much blessing has come to the work as a result of them. The late Rev. T. Walker of Tinnevelly was appointed to attend such gatherings as representing the Keswick Convention; his ministry was also an immense spiritual force amongst the Syrian Christians at Travancore through his annual visits to their convention at Maramanna.

South Africa has been visited on several occasions; a missionary writing from Natal tells of very definite blessing received at Durban during the visit of the last deputation.

The Rev. Charles Inwood, a minister of the Wesleyan Methodist Church and one of the leading speakers at Keswick, has on nine different occasions undertaken work abroad, visiting China, India, Egypt, South America (twice), South Africa, Palestine, British Central Africa, and Jamaica. His ministry has been highly appreciated and greatly blessed, and the record of his visit to Central Africa in 1910 tells of a wonderful exhibition of the power of the Spirit of God.

Four deputations have visited China and conventions have been held in six different centres for the missionaries. The writer has had the privilege of taking part in two of these deputations and he can tell from personal experience of blessing of a very marked character amongst the missionaries.

Twenty-five missionaries in all have been sent out to 
various countries and supported from the Keswick Mission Fund. These have all been connected with recognized missionary societies under whose direction they carry on their work.

At the present time when attention is being directed afresh to the question of the missionary motive, it may be well in closing to indicate again the motive that lies behind the movement we have been considering. It has consisted essentially in the love of God in the sacrifice of His Son, so presented as to claim and call forth a corresponding sacrifice in the lives of His servants.

Walter B. Sloan 